\title{
IAMJ
}

INTERNATIONAL

AYURVEDIC

MEDICAL JOURNAL

ISSN: 2320-5091

Impact Factor: 6.719

\section{ROLE OF AYURVEDA IN THE MANAGEMENT OF ARDITA (BELL'S PALSY) - A CASE REPORT}

\author{
Seema Bahatkar' ${ }^{1}$, Rajiv Tarpe ${ }^{2}, \underline{\text { Kinjal H. Daiyya }}^{3}$ \\ ${ }^{1}$ HOD, Department of Panchakarma, R.A Podar Medical College, Worli, Mumbai, India \\ ${ }^{2}$ Assistant Professor, Department of Panchakarma, R.A Podar Medical College, Worli, Mumbai, India \\ ${ }^{3}$ P.G Scholar $3^{\text {rd }}$ Year, Department of Panchakarma, R.A Podar Medical College, Worli, Mumbai, India
}

Corresponding Author: kinjaldaiyya@gmail.com

https://doi.org/10.46607/iamj4709082021

(Published Online: August 2021)

Open Access

(C) International Ayurvedic Medical Journal, India 2021

Article Received: 22/07//2021 - Peer Reviewed: 02/08/2021 - Accepted for Publication: 03/08/2021

\section{Check for updates}

\begin{abstract}
Ardita is considered as one amongst the vata nanatmaj vyadhis described in Ayurvedic classics. Ardita is a condition caused due to the unusual functioning of vata dosha which results in loss of functioning of one half of the face. It can be correlated with Bell's Palsy from modern perspective. This disease proves to be disturbing from a functional and cosmetic point of view. A 27year old male patient came to OPD with a chief complaint of difficulty in closing right eye, angle deviation of the mouth towards left, difficulty while eating, unable to whistle as well as puffing of cheeks, drooling of saliva, etc. from 20 days. History and examination lead to the diagnosis of Bell's Palsy. Considering the signs and symptoms, the patient was treated as per the ayurvedic line of treatment for Ardita. The patient was admitted and ayurvedic treatment (Panchakarma + Oral medications) i.e. Nasya, Pindasweda, Kukkutanda sweda, Akshitarpan was given for 21days. The patient had great relief with marked improvement in the above said symptoms. Thus, Ayurveda is fruitful in treating patients with Ardita.
\end{abstract}

Keywords: Ardita, Nasya, Pindasweda, Kukkutanda sweda, Akshitarpan 


\section{INTRODUCTION}

Ardita is considered as one amongst the Vata nanatmaj vyadhis described in Ayurvedic classics ${ }^{1}$. Acharya Charak opines that this disease is localized in one half of the face with or without the involvement of the body $^{2}$. The same is the opinion with Acharya Vagbhat $^{3}$. Acharya Sushruta says face is only affected in Ardita. It is the condition caused due to vitiated vata dosha, which turns the face in the opposite direction ${ }^{4}$. The face is the mirror of the mind which conveys emotions like happiness, sadness, anger, fear, disgust, etc. also, man is recognized with his skill of communication. The disability in communication skills and facial expressions are hampered in Ardita, a vata vyadhi which is more common in the present day. When vata dosha is functioning normally in the body, it is responsible for the proper functioning of all sense organs but once in the abnormal state may lead to morbidity. The causative factors for this particular disease wherein vata is vitiated primarily are described in Ayurvedic texts as carrying heavyweight on the head, excessive laughing, speaking loudly, sudden fear, lying on the uneven bed, eating or chewing hard food substances, etc $^{3,4}$. Clinical features according to Ayurvedic classics are half sided facial deformity including nose, eyebrows, forehead, eyes, tongue and chin region on affected site, slurring of speech, deafness, partial closure of eyes, disturbing smell sensation. Bell's Palsy is an acute, idiopathic, commonly unilateral lower motor neuron type of facial nerve involvement due to nonsupportive inflammation of nerve within the facial canal above stylomastoid foramen. Bell's Palsy has an incidence of 1 in 60 to 70 people in a lifetime. The facial nerve controls several functions such as blinking and closing the eyes, smiling, frowning, lacrimation, salivation, raising of eyebrows, flaring of nostrils, the sensation of taste in the anterior $2 / 3^{\text {rd }}$ of the tongue which is affected in Bell's Palsy ${ }^{5}$. Medical treatment for Bell's Palsy includes corticosteroids, antiviral agents. Approximately $80-90 \%$ of patients recover without noticeable disfigurement within 6 weeks to 3 months. The reoccurrence rate is $4-14 \%^{6}$. Line of treatment in Ardita includes Nasya (nasal instillation of medicine), Murdhni tel (application of oil to head), Nadi Sweda (steam through the tube), Upnaah (sudation in which medicaments are heated and tied in a sterile cloth/ made into bolus) ${ }^{7}$. Acharaya Vagbhat has also mentioned Karnapooran (instillation of oil in ears), Akshitarpan (treatment which nourishes the eye $)^{8}$. Keeping in view the above-said treatment, the patient was treated accordingly, and the case was studied to evaluate the effect of traditional ayurvedic methods and procedures in the management of Bell's Palsy. AIM and OBJECTIVES- To evaluate the efficacy of Ayurvedic treatment in Ardita.

\section{CASE REPORT}

A 27-year-old male patient came to OPD with a chief complaint of difficulty in closing right eye, angle deviation of the mouth towards left, difficulty while eating, unable to whistle as well as puffing of cheeks, etc. from 20 days. He had no history of hypertension, diabetes mellitus or any other major illness as well did not have any addiction. The patient was a retailer by occupation. On taking a detailed history, it was noted that 3days before the onset of Bell's Palsy, he had been to Lonavala with friends. Had travelled through bus and both the times i.e while going and returning had sat on the window seat with the window open. Above that, he had played in a waterfall for 3hours and got a neck sprain while playing. 3days after returning from Lonavala he faced the above problems and was diagnosed as Bell's Palsy and was admitted to hospital for 1day. He took allopathic treatment for 20days which consisted of corticosteroids, antiviral drugs and topical ocular drops. The patient did not find any significant result so opted for ayurvedic treatment. After reviewing, he was diagnosed as Ardita and was admitted for 21days. Ayurvedic line of treatment consisted of Nasya with Anu tail, Shashtishali Pindaswed for 14days followed by Kukkutanda Pindaswed for 7days, Shirodhara with Jatamansi siddh teel tel, Akshitarpan with Triphala grit, Sneha gandush and facial exercises. 
Table 1: Panchakarma treatment given with duration

\begin{tabular}{|l|l|l|l|}
\hline Sr. no. & Treatment given & Drug & Duration \\
\hline 1. & Nasya & Anu tail & 21days \\
\hline 2. & Shashtishali Pindaswed & & 1 ddays \\
\hline 3. & Kukkutanda Pindaswed & & 7 days $\left(15^{\text {th }}-21^{\text {st }}\right.$ day $)$ \\
\hline 4. & Shirodhara & Jatamansi siddh teel tel & 10 days \\
\hline 5. & Akshitarpan & Teel tel + Lukewarm water & 14days \\
\hline 6. & Sneha gandush & 21days \\
\hline
\end{tabular}

Internally, the patient was given -

1. Ekanveer ras $125 \mathrm{mg} \mathrm{BD}$,

2. Yograj Guggulu 500mg BD,

3. Ashwagandha + Guduchi churna $5 \mathrm{gm} \mathrm{BD}$

4. Gandharva Haritaki churna $3 \mathrm{gm}$ HS.

The patient was explained about proper diet and lifestyle management. The result experienced in 21 days was very encouraging.

\section{Clinical Findings on Examination-}

1. EYE- Unable to fully close Right eye.

Dryness of Right eye

Unable to raise Right eyebrow.

2. Unable to puff cheeks.

3. Unable to whistle.

4. Difficulty while speaking.

5. Deviation of the angle of the mouth towards the Left.

6. Flaring of R nostril - Absent.

Assessment Criteria- Done based on House Brackmann Grading System ${ }^{9}$

Table 2: Assessment Criteria

\begin{tabular}{|c|c|c|c|c|c|}
\hline Clinical Feature & Grading & Score & BT & AT & $\%$ Relief \\
\hline \multirow{4}{*}{$\begin{array}{l}\text { Dryness of } \\
\text { Right Eye }\end{array}$} & No dryness & 0 & \multirow{4}{*}{2} & \multirow{4}{*}{1} & \multirow{4}{*}{$50 \%$} \\
\hline & $\begin{array}{l}\text { Persistent but do not disturb routine } \\
\text { work }\end{array}$ & 1 & & & \\
\hline & Persistent and disturbs routine work & 2 & & & \\
\hline & Constant dryness & 3 & & & \\
\hline \multirow{4}{*}{$\begin{array}{l}\text { Widening of Palpebral } \\
\text { aperture } \\
\text { (Netravikriti) }\end{array}$} & No widening & 0 & \multirow{4}{*}{2} & \multirow{4}{*}{1} & \multirow{4}{*}{$50 \%$} \\
\hline & Slightly wide (Whole cornea visible) & 1 & & & \\
\hline & $\begin{array}{l}\text { Moderately wide (Cornea and } 1 / 3^{\text {rd }} \text { of } \\
\text { upper sclera visible) }\end{array}$ & 2 & & & \\
\hline & $\begin{array}{l}\text { Severely wide (Cornea and } 1 / 2 \text { of up- } \\
\text { per sclera visible) }\end{array}$ & 3 & & & \\
\hline \multirow{4}{*}{$\begin{array}{l}\text { Absence of nasolabial } \\
\text { fold }\end{array}$} & Nasolabial fold present normally & 0 & \multirow{4}{*}{2} & \multirow{4}{*}{0} & \multirow{4}{*}{$100 \%$} \\
\hline & $\begin{array}{l}\text { The nasolabial fold is seen while try- } \\
\text { ing to speak }\end{array}$ & 1 & & & \\
\hline & $\begin{array}{l}\text { The nasolabial fold is seen while at- } \\
\text { tempting to smile }\end{array}$ & 2 & & & \\
\hline & Nasolabial fold never seen & 3 & & & \\
\hline \multirow[t]{3}{*}{ Smiling sign } & Absent & 0 & \multirow[b]{3}{*}{2} & \multirow[b]{3}{*}{1} & \multirow[b]{3}{*}{$50 \%$} \\
\hline & $\begin{array}{l}\text { Smiling sign present without upward } \\
\text { movement of L angle of mouth }\end{array}$ & 1 & & & \\
\hline & $\begin{array}{l}\text { Smiling sign present with upward } \\
\text { movement of } L \text { angle of mouth }\end{array}$ & 2 & & & \\
\hline
\end{tabular}




\begin{tabular}{|c|c|c|c|c|c|}
\hline & Smiling sign present all the time & 3 & & & \\
\hline \multirow{4}{*}{$\begin{array}{l}\text { Slurring of speech } \\
\text { (Vaaksang) }\end{array}$} & Normal speech & 0 & \multirow{4}{*}{1} & \multirow{4}{*}{0} & \multirow{4}{*}{$100 \%$} \\
\hline & Pronouncing with fewer efforts & 1 & & & \\
\hline & Pronouncing with great efforts & 2 & & & \\
\hline & Complete slurring & 3 & & & \\
\hline \multirow{4}{*}{$\begin{array}{l}\text { Dribbling of saliva } \\
\text { from } \mathrm{R} \text { corner of the } \\
\text { mouth (Lalastraav) }\end{array}$} & Absent & 0 & \multirow{4}{*}{2} & \multirow{4}{*}{0} & \multirow{4}{*}{$100 \%$} \\
\hline & Intermittent dribbling & 1 & & & \\
\hline & Constant but mild dribbling & 2 & & & \\
\hline & Constant but profuse dribbling & 3 & & & \\
\hline \multirow{4}{*}{$\begin{array}{l}\text { Earache } \\
\text { (Karnashoola) }\end{array}$} & No pain & 0 & \multirow{4}{*}{1} & \multirow{4}{*}{0} & \multirow{4}{*}{$100 \%$} \\
\hline & Intermittent & 1 & & & \\
\hline & Persistent and do not disturb routine & 2 & & & \\
\hline & Persistent and does disturbs routine & 3 & & & \\
\hline
\end{tabular}

Assessment of total effect- Complete Cure - 100\%

Marked relief - > 50\%

Moderate response - > 25\% - 50\%

No response $-0 \%$

There was marked relief noted in the patient.

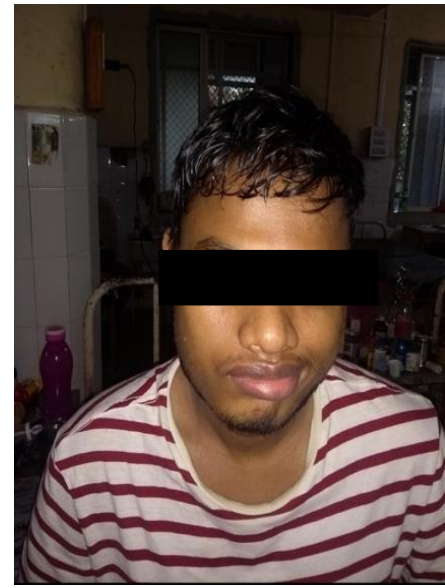

On $1^{\text {st }}$ Day

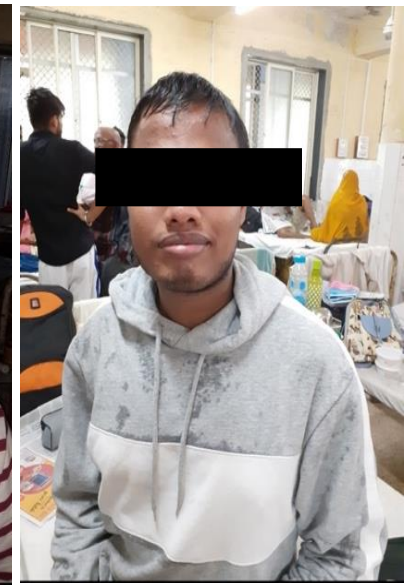

On $21^{\text {st }}$ Day

\section{DISCUSSION}

In this case, the hetu is travelling, continuous exposure to wind with its impact on the ear as well as playing in a waterfall. Due to excessive exposure to cold wind, vitiated vata with kapha is involved in the occurrence of disease. Prakrupit vata (vitiated vata) enters in all the empty channels of the body and then creates 80 types of vata nanatmaj vyadhis like Ardita, Pakshaghat (Hemiplegia), joint disorders, etc. In this case, exposure to cold wind vitiated vata with kapha; settles in sandhi's of Shira (Head), Nasa (Nose), Hanu (Mandible), Lalata (forehead) and Netra (eye), Snayu (ligament) and Kandara (tendons). These are affected by dosha's presenting symptoms on the Right half of the face.

\section{PROBABLE MODE OF ACTION-}

SNEHAN with Mahanarayan tel before nasya, pindasweda stimulates the sensory nerve endings and provide strength to facial muscles ${ }^{10}$. Swedan enhances local microcirculation by dilation of blood vessels and increased blood flow to the area as well as accelerates drug absorption. Also, swedana is said to be the best form of treatment in expelling morbid vata and kapha doshas and destroying diseases arriving because of $\mathrm{it}^{11}$. Shashti Shaali Pindasweda is helpful in vatavikara, neurological disorders, neuralgia, paralysis. Is an effective rejuvenation therapy; relaxes the body, strengthens muscles, improve blood circulation. Kukkutanda sweda is a form of Snigdha pindasweda which causes a local rise in temperature mainly due to ushna, teekshna guna of drugs present in it. There's vasodilation of localized blood vessels which stimulates Bhrajak Pitta in the skin, taking up the nutrients from kukkutanda and other drugs and promotes the removal of metabolic waste through circulation and sweat. Also, the drugs after coming in contact with the skin undergo metabolism by the action of Bhrajakagni and rasdhatwagni. It further leads to the nourishment of rasaadi dhatu because of vyaan vayu. The process combats the sheeta, laghu and ruksha properties of vata dosha thereby reducing shoola and stambha ${ }^{12}$. Shirodhara categorized under Murdhni tel is highly effective in vata related disorders and disorders affecting 
the body, mind, and sense organs. Jatamansi oil calms down the brain, relieves anxiety and is well known in neurological disorders because of its Medhya property (improves brain functions) $)^{13}$. Gandusha improves voice and speech, strengthens the jaw as well as facial muscles which are weakened by prakupita vata dosha. Sneha gandush is indicated in vata vyaadhi and teel tel possesses vatahara properties ${ }^{14}$. Nasya is indicated in urdhwajatrugata rogas and nasa is considered as one of the panchgyanendriya whose functions are not only restricted to olfaction and respiration but is also considered as a pathway for the administration of drugs. Medicine given through nostrils travels the entire passage and reaches the cribriform plate which is porous. From there it is absorbed and reaches the tissue of the brain. Also, in the texts, it's said Nasya is fruitful in Ardita. ${ }^{15}$ Akshitarpan relieves the symptoms by improving the movement of eyelids, nourishing the eye and relieving dryness of the eye. Facial exercises like blowing the balloon, pronouncing vowels, etc. Ekangveer ras acts as Vataghna, Brihana, Rasyana, Vishaghna which helps in speedy recovery. Yograj guggulu is helpful in all vatavyadhi, is tridoshaghna as well as rasayana ${ }^{16}$.

\section{CONCLUSION}

From the present case study, it can be concluded that the Ayurvedic treatment described in the text is fruitful in relieving the signs and symptoms of the disease. All the therapies like Nasya, Shirodhara, Pindasweda, etc as a combined treatment pacifies Vata dosha and provides nourishment to the sense organs. Moreover, internal medications and exercise have an add-on effect. Thus, Ayurveda helps in improving the day-to-day life of the patient suffering from Ardita.

Declaration of Patient Consent- The authors certify that they have obtained his consent for the images and other clinical information to be reported in the journal. The patient understands that his name and initials will not be published in the journal.

\section{REFERENCES}

1. Shukla V. and Tripathi R; Charak Samhita by Acharya Charak; vol.1; Chaukhamba Prakashan, Delhi; Edition 2013; sutra sthan 20/11; pg no. 293

2. Shukla V. and Tripathi R; Charak Samhita by Acharya Charak; vol.2; Chaukhamba Prakashan, Delhi; Edition 2013; chikitsa sthan 28/38-42; pg no. 694

3. Tripathi B; Astanga Hridayam of Srimad vagbhat, Chaukhamba Pratisthan, Delhi, Edition 2013, nidansthan 15/32-36; pg no. 541

4. Sharma A.; Susruta Samhita of Maharshi Susruta; vol. 1; Chaukhamba Surbharati Prakashan, Varanasi; Edition 2013; nidansthan 1/69-72: pg. no. 467

5. M. Flint Beal, Stephen L. Hauser, Harrison's Internal Medicine, Trigeminal neuralgia, Bell's Palsy and other cranial nerve disorders, $17^{\text {th }}$ Edition, Part 16, pg. no. 2584.

6. Bell's Palsy - Facial Palsy UK available at www.facialpalsy.org.UK/causes and diagnosis/ bell's palsy/ http://patient.info/doctor/facial-nerve palsy\#ref 11

7. Shukla V. and Tripathi R; Charak Samhita by Acharya Charak; vol.2; Chaukhamba Prakashan, Delhi; Edition 2013; chikitsa sthan 28/99; pg no. 705

8. Tripathi B; Astanga Hridayam of Srimad vagbhat, Chaukhamba Pratisthan, Delhi, Edition 2013, nidansthan 15/43; pg no. 809

9. Shikha et al. Ayurvedic management of Ardita (Bell's Palsy): A Case Study- International Journal Of Ayurveda and Pharma Research 2017; 5(4): 62-65

10. Shukla V. and Tripathi R; Charak Samhita by Acharya Charak; vol.1; Chaukhamba Prakashan, Delhi; Edition 2013; sutra sthan 13/15; pg no. 199

11. Shukla V. and Tripathi R; Charak Samhita by Acharya Charak; vol.1; Chaukhamba Prakashan, Delhi; Edition 2013; sutra sthan 14/21; pg no. 220Yy

12. Yadav M. et al. Conceptual Study on Kukkutanda Pinda Sweda: A Review Article. Research and Reviews: A Journal of Health Professions. 2020; 10(3): $14-18 \mathrm{p}$

13. Tripathi B; Astanga Hridayam of Srimad vagbhat, Chaukhamba Pratisthan, Delhi, Edition 2013, sutrasthan 22/34; pg no. 262

14. Shukla V. and Tripathi R; Charak Samhita by Acharya Charak; vol.1; Chaukhamba Prakashan, Delhi; Edition 2013; sutra sthan 5/78-80; pg no. 99

15. Shukla V. and Tripathi R; Charak Samhita by Acharya Charak; vol.1; Chaukhamba Prakashan, Delhi; Edition 2013; sutra sthan 5/78-80; pg no. 96 
16. Tripathi B.; Sharangdhar Samhita; Chaukhamba Publication; Varanasi; Edition 2016; Uttar khand 8/46; pg no. 249 .

\section{Source of Support: Nil \\ Conflict of Interest: None Declared}

How to cite this URL: Kinjal H. Daiyya et al: Role Of Ayurveda In The Management Of Ardita (Bell's Palsy) - A Case Report. International Ayurvedic Medical Journal \{online\} 2021 \{cited August 2021\} Available from: http://www.iamj.in/posts/images/upload/1898_1903.pdf 